\title{
Soil microbiome in chronosequence of spoil heaps of Kursk Magnetic Anomaly
}

\section{Ekaterina Ivanova ${ }^{1,3,4}$, Elizaveta Pershina ${ }^{1,2}$, Dina Karpova ${ }^{5}$, Olga Rogova ${ }^{3}$, Evgeny Abakumov', and Evgeny Andronov ${ }^{1,2,3}$}

${ }^{1}$ Federal State Budget Scientific Institution "All-Russian Research Institute of Agricultural Microbiology", Shosse Podbelskogo, 3, Saint Petersburg, 196608, Russian Federation 2Department of Applied Ecology, Faculty of Biology, Saint Petersburg State University, $16^{\text {th }}$ Liniya V. O., 29, Saint Petersburg, 199178, Russian Federation

${ }^{3}$ V. V. Dokuchaev Soil Institute, Pyzhyovskiy Lane, 7 (building 2), Moscow, 119017, Russian Federation

${ }^{4}$ Agrophysical Research Institute, Grazhdanskii Pr., 14, Saint Petersburg, 195220,

Russian Federation

${ }^{5}$ Lomonosov Moscow State University, 1-12 Leninskie Gory, Moscow, 119234,

Russian Federation

Address correspondence and requests for materials to Ekaterina Ivanova, ektrnivanova@gmail.com

\section{Abstract}

The physicochemical parameters, vegetation and biodiversity of microbiomes inhabiting 10-, 35- and 50-year-old embryonic soils (technozems) formed in the mining areas of the Kursk Magnetic Anomaly (Russia) were analyzed in the current study. Analysis of taxonomic diversity was carried out by 454-pyrosequencing of the V4 variable region of the $16 \mathrm{~S}$ rRNA gene. All points of the chronosequence were characterized by microbiomes reliably differing in taxonomic composition. The older the dump, the higher the proportion of bacteria from the phyla Actinobacteria (mostly representatives of the Solirubrobacteriaceae family), Chloroflexi and Acidobacteria in the community. In 10-year-old dumps, bacteria from the phyla Proteobacteria, Gemmatimonadetes and Bacteroides prevailed. The most pronounced changes in the community structure at the early and middle stages of microbiological succession were demonstrated by bacteria from the genus Delftia, which may indicate their active role in the processes of soil formation in this ecosystem.

Keywords: microbial communities, embryonic soils, 454-pyrosequencing, $16 \mathrm{~S}$ rRNA, overburden rock dumps.

\section{Introduction}

Soil genesis is closely associated with the activity and evolution of its microbiome (Wolińska et al., 2018). Microorganisms play a key role in ensuring the cycles of the basic biogenic elements, in the processes of decomposition of organic material, and in the formation of soil organic matter. Also, soil microorganisms are able to utilize a wide range of chemical compounds, thereby participating in the bioremediation of disturbed areas (Schütz et al., 2010; Dzionek, Wojcieszy and Guzik, 2016; Wolinska et al., 2016). Because of the important ecosystem functions mediated by microorganisms in the soil, recovery of the soil microbial community is a critical step in achieving the goal of soil restoration for its sustainable and beneficial use (Rana, Stahl, Ingram, and Wick, 2007).

The promising model objects are soil chronosequences, where the processes of soil restoration can be observed in development within certain time intervals. A number of such objects are well known, including Antarctic soils (Nemergut et al., 2007; Bradley, Singarayer, and Anesio, 2014), volcanic ash-covered areas (Gomez-Alvarez, King, and Klaus, 2007), post-fire ecosystems (Goberna et al., 2005; Sun et al., 2017), as well as the areas of mining and storage for rock dumps (Spro-

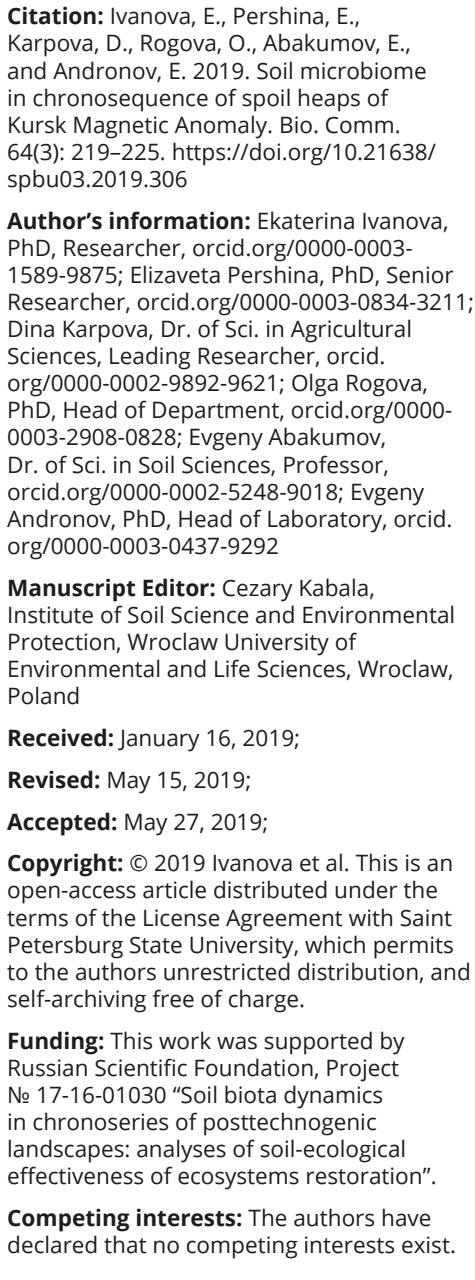


cati et al., 2014; Gadd, 2019). The advantage of using chronoseries is the precise dating of the age of the dump, which makes it possible to construct predicative models of the soil-forming process, identify the associated microbial succession in the regeneration of disturbed soils, and assess the rate and nature of soil formation.

The investigation of microbiomes during primary succession on mining sites has been broadly used in soil biology for the past 20 years. The interest in these studies is partially due to the huge area destroyed by mining activity and partially because of the prime role of microorganisms in the successful adaptation and development of the plant community during the spontaneous succession of the biocenosis. Many publications have been devoted to the study of the microbial communities of reclaimed soils, containing valuable information on the rates of biomass restoration, diversity and the activity of microbial communities in the chronoseries of soils in technogenic landscapes (Frouz and Novakowa, 2005; Claassens, Rensburg, and Rensburg, 2006; Harantová, Frouz, Elhottová, and Baldrian, 2017). It was revealed that the structure and composition of microbiomes are determined by a combination of physical and physicochemical parameters (soil organic matter and total nitrogen content, $\mathrm{pH}$, cation exchange capacity of soils), the values of which were significantly higher in reclaimed variants. Great attention is paid to the use of microbial communities as indicators of various stages of soil restoration in technogenic landscapes (Dwivedi and Soni, 2011; Harantová et al., 2017).

In Russia, despite the existence of various chronosequences and a huge variety of soils, such studies have been conducted generally by application of classical microbiological practices. However, as soil is the largest depository of microbial biodiversity on our planet, and one gram of it can contain up to $1000 \mathrm{~Gb}$ of genetic information belonging to billions of microbial cells, access to the study of the whole microbial diversity could be provided by using modern molecular-genetic methods and techniques (Thomas, Gilbert, and Meyer, 2012; Wolińska et al. 2018).

The purpose of this work was to study the taxonomic structure of the soil microbiome in the chronosequences of soils of various ages on the Kursk Magnetic Anomaly (KMA) dumps, formed mainly by Callovian clays - the main soil-forming rock of this geographic region.

\section{Materials and Methods}

The objects of this study were samples originating from embryonic soils formed on the dumps of one of the most famous industrial companies involved in iron ore mining - spoil heaps of the KMA.An expedition to the region of the Kursk Magnetic Anomaly was organized to study the process of primary soil formation in the conditions of technogenic landscapes. The main parent rock in the area of the Mikhailovsky mining complex (KMA) was a mixture of tertiary Callovian clays (Upper Jurassic) (dominating) and Bat sands. For the analysis, sites were chosen on the dumps of 10 years, 35 years and 50 years of age (CL1-3, respectively, N 52,2592436; E $35,3708321)$. The soil samples were taken from the upper soil horizon of each of them (at a depth of 0-10 cm). All samples were accompanied by a geobotanical description of the sites, as well as by the main soil physicochemical parameters (Table 2). Sampling was carried out in triplicate, from the middle of the $0-10 \mathrm{~cm}$ layer.

DNA extraction was performed using the PowerSoil $^{\circledR}$ DNA Isolation Kit (MO BIO, USA), including the step of mechanical destruction of a soil sample using abrasive materials (Mobio Laboratories, USA). The destruction of the soil sample was carried out on a Precellys 24 homogenizer (Bertin Technologies, France). The purity of isolation and the amount of isolated DNA were checked by electrophoresis in $1 \%$ agarose in $0.5 \mathrm{x}$ TAE buffer. The average DNA concentration in the sample was $50 \mathrm{ng} / \mathrm{ml}$.

The purified DNA preparates (10-15 ng) were used as templates in the PCR reaction (temperature profile: $95^{\circ} \mathrm{C}-30 \mathrm{~s}, 50^{\circ} \mathrm{C}-30 \mathrm{~s}, 72^{\circ} \mathrm{C}-30 \mathrm{~s}, 30$ cycles in total) using Encyclo polymerase (Eurogen, Russia) and universal primers to the V4 variable region of the $16 \mathrm{~S}$ rRNA gene: F515 (GTGCCAGCMGCCGCGGTAA) and R806 (GGACTACVSGGGTATCTAAT). The primers included oligonucleotide barcodes for each sample and the service sequences required for 454-pyrosequencing by Roche protocol (Roche, Switzerland). Sample preparation and sequencing were performed on a GS Junior device (Roche, Switzerland) according to the manufacturer's recommendations.

Downstream processing of the 16S rRNA gene libraries was performed using the QIIME software package (Caporaso et al., 2010). At the first stage, the sequence quality was verified. Sequences smaller than 200 nucleotides in length, with a quality score of less than 25 , containing incorrectly read primer and multiplex identifier sequences, as well as extended homopolymeric repeats (more than eight nucleotides) and unidentified nucleotides were excluded from the analysis. Also, all non-bacterial and chimeric sequences were excluded from further analysis. The data were normalized according to the number of sequences in the library of the smallest size. As a result of all of these procedures, 14,312 sequences were selected. After the data normalization procedure, the number of sequences in each library was 4700 . Sequences with similarity over $97 \%$ were combined into operational taxonomic units (OTUs) using a de novo algorithm (based on the UCLUST method). From each OTU, one sequence was chosen to compose a set of representatives. The next 
Table 1. Vegetation description of the embryozems formed on the overburden dumps of KMA

\begin{tabular}{|c|c|c|}
\hline Sample ID & Parent material & Plant community composition \\
\hline CC_10 & \multirow{3}{*}{$\begin{array}{l}\text { Bat-Callovian } \\
\text { deposits }\end{array}$} & $\begin{array}{l}\text { Sparse, scrubby vegetation, lacking a tree and shrub tier. Synusia of Tusellago farfara, Salsola collina, } \\
\text { tumbleweed, Polygonum persicaria. Underbrush of Acer negundo. Presence of Medicago lupulina, Trifolium } \\
\text { medium, Trifolium repens, Trifolium hybridum, Vicia cracca, Calamagrostis canescens. }\end{array}$ \\
\hline CC_35 & & $\begin{array}{l}\text { Tree tier: Pinus sylvestris, Betula pendula; undergrowth: Pinus sylvestris, Populus tremula; grassy tier - } \\
\text { meadow-motley grass community: synusia of Calamagrostis canescens, Pilosella officinarum, down the } \\
\text { hill - synusia of Tussilago farfara and Cirsium vulgare; single plants of Silene pratensis, Fragaria vesca, } \\
\text { Linaria vulgaris, Trifolium repens, Achillea millefolium; a significant area was covered with two types of } \\
\text { moss }\end{array}$ \\
\hline CC_50 & & $\begin{array}{l}\text { Plantations of Betula pendula and Populus tremula, the formula of the stand: } 5 \mathrm{~B} 5 \mathrm{O} \text { (B - birch, O - } \\
\text { aspen), a single plant of Pinus sylvestris, underbrush of Querqus robur; eatage: Populus tremula, Pinus } \\
\text { sylvestris, Betula pendula; the grassy sward is strongly rarefied, high shoots of dead plants are present in } \\
\text { large numbers, synusia of Calamagrostis epigeus and Festuca pratensis, in the gaps - vegetating Pilosella } \\
\text { officinarum, occurring: Artemisia vulgaris, Vicia cracca, Trifolium medium, Achillea millefolium, Trifolium } \\
\text { pretense. }\end{array}$ \\
\hline
\end{tabular}

stage was the classification of representative sequences using the RDP naïve Bayesian rRNA Classifier program and PyNast algorithm alignment (Caporaso et al., 2010), and a specially designed set of sequences, Greengenes coreset (DeSantis et al., 2006) was used to align the sequences. The aligned sequences were used to construct the distance matrix and phylogenetic tree.

To assess biodiversity and conduct comparative anal$y$ sis of communities, the parameters of $\alpha$ - and $\beta$-diversity were calculated. The $\alpha$-diversity was assessed using the index of species richness (the number of OTUs in the sample) and the Shannon index. The reliability of differences in $\alpha$-diversity indices among microbiomes was assessed using the t-test. To assess the $\beta$-diversity, the weighted unifrac method was used, which allows estimating the percentage of similarities/differences between all pairs of compared microbiomes (Caporaso et al., 2010). To represent the results of the analysis, the methods of multidimensional statistics (analysis of the main components) using the Emperor program were employed.

To assess the reliability of differences in the representation of individual taxa in the analyzed samples, in addition to the QIIME software, a script was written using the programming language Python. This script performs multiple pairwise tests of contingency tables of OTU frequencies in different collections of samples/ replicates. The algorithm dynamically chooses either the G-test or the Fisher exact test depending on the circumstances and applies Bonferroni p-value correction.

\section{Results and Discussion}

\section{VEGETATION}

Technozems (Lithosols Technic) of the very initial staged dumps were dominated by grasses, while the sparse forests with dominance of birch and poplar were typical for older stages. During the study, 22 plant species were described (Table 1). The number of species was relatively low in comparison to the previous geobotanical observation of the territory (Stifeev, Golovastikova, and Bessonova, 2011). The reason can be the season when the study was conducted: soil sampling was carried out in September, when the majority of plants are already at the terminal vegetation stage. The major groups are partially similar with species described previously (Stifeev and Golovastikova, 2015). However, only CC_50 samples (50-year dumps) were characterized by $100 \%$ plant cover.

\section{SOIL PHYSICOCHEMICAL CHARACTERISTICS OF THE SAMPLES}

Soils of the studied dumps were presented mainly by weakly developed profiles of Lithosols (embryozems) with well-pronounced accumulation of organic matter in the topsoil (at late stages of succession). No significant alteration of the majority of soil physicochemical properties, as well as the soil structure and texture composition with the age of the dumps, were revealed. The embryozems were generally characterized by an increased content of trace elements, including heavy metals (TM) in comparison with values of MAC, APC (at $\mathrm{pH}>5.5)$ and background value (Brindukova, 2010) in the region.

The $\mathrm{pH}$ of embryozems was slightly alkaline and fluctuated around 8.0, while the $\mathrm{pH}$ of the pristine soil environment was slightly acid. The reason is the composition of the rocks, for instance, a relatively high content of carbonates here.

Increased levels of available potassium can be attributed to the high ability of clays to absorb potassium in a non-exchangeable form (Kovda, 1965). The amount of available phosphorus did not change significantly.

Iron content was high both in the soils on the embryozems and in the background soils, which is associated with the particular features of the KMA region. At 
Table 2. Physicochemical analysis of samples of the embryozems formed on the overburden dumps of KMA

\begin{tabular}{lccccccccccccc}
\hline Sample ID & Soil moisture & $\mathrm{pH}$ & Corg. & Ntot. & $\mathrm{CaCO}_{3}$, & $\mathrm{Pav}_{\text {av }}$ & $\mathrm{K}_{\mathrm{av} .}$ & $\mathrm{Cu}$ & $\mathrm{Ni}$ & $\mathrm{Pb}$ & $\mathrm{Zn}$ & $\mathrm{Rb}$ & $\mathrm{Sr}$ \\
\hline & \%, gravimetric & & & $\%$ & & $\mathrm{mg} / 100 \mathrm{~g}$ of soil & & & $\mathrm{mg} / \mathrm{kg}$ of soil & \\
CC_10 & 19.28 & 6.80 & 1.15 & 0.06 & 5.70 & 6.32 & 23.52 & 15 & 31 & 0 & 57 & 49 & 126 \\
CC_35 & 24.99 & 8.13 & 1.46 & 0.05 & 14.37 & 1.79 & 47.96 & 15 & 33 & 14 & 74 & 108 & 169 \\
CC_50 & 22.78 & 8.12 & 2.41 & 0.20 & 15.95 & 4.85 & 53.69 & 23 & 37 & 17 & 88 & 106 & 146 \\
\hline
\end{tabular}

Table 3. Mantel R statistics values for the samples of embyozems formed on the overburden dumps of KMA

\begin{tabular}{|c|c|c|c|c|c|c|c|c|c|c|c|c|}
\hline Corg & Ntot & $\mathrm{pH}$ & Pav & Kav & $\mathrm{CaCO}_{3}$ & $\mathrm{Fe}$ & $\mathrm{Cu}$ & $\mathrm{Ni}$ & $\mathrm{Pb}$ & $\mathrm{Zn}$ & $\mathrm{Sr}$ & $\mathrm{Rb}$ \\
\hline \multicolumn{13}{|c|}{ Mantel R_statistics } \\
\hline \multirow[t]{2}{*}{0.38} & 0.44 & 0.79 & 0.76 & 0.15 & 0.83 & 0.83 & 0.39 & 0.04 & 0.89 & 0.92 & 0.91 & 0.79 \\
\hline & & & & & $p$-value & & & & & & & \\
\hline 0.028 & 0.010 & 0.011 & 0.003 & 0.349 & 0.003 & 0.004 & 0.024 & 0.805 & 0.003 & 0.001 & 0.001 & 0.002 \\
\hline
\end{tabular}

the same time, there was only a weak tendency for the iron content to change with time (Table 2). The lack of correlation of iron content with age is probably due to the low mobility of iron under conditions of natural and slightly alkaline $\mathrm{pH}$ (Brindukova, 2010).

Nitrogen and carbon content increased with soil age. Nitrogen was actively consumed by vegetation, and its amount in the soil was related to its content in organic compounds. Moreover, the dumped rocks almost lack nitrogen, and its accumulation in soil occurs due to symbiotic and free-living microorganisms (Nemergut et al., 2007). Therefore, an increase in the nitrogen content in embryozems from the earliest to the latest stages of technogenic landscapes is associated with a similar accumulation of organic carbon. The C: $\mathrm{N}$ ratio in the embryozems displayed a low and very low enrichment of humus with nitrogen, which is typical for horizons containing slightly humified plant residues.

According to the Mantel test results, almost all of the main physicochemical parameters caused a significant impact on the structure of microbial community (Table 3).

\section{ANALYSIS OF PROKARYOTIC COMMUNITY OF THE SOIL CHRONOSEQUENCE}

When analyzing the taxonomic structure of the microbiome, 29 bacterial and 2 archaeal phyla were found in the soil samples of the dumps. On average, $0.5 \%$ of the sequences were not identified to the domain level. Among the bacteria in the community, representatives of phyla Proteobacteria ( $41.7 \%$ on average), Actinobacteria (34\%), Chloroflexi (10.4\%), Gemmatimonadetes (4.5\%), Acidobacteria (2.5\%), Bacteroidetes (2\%), Planctomycetes (1.1\%) (Fig.1a) were noted as dominants; meanwhile other phyla on average did not exceed $1 \%$ per library.
When comparing the early and late stages of the investigated microbial succession, the percentage and taxonomic diversity of bacteria from phyla Actinobacteria, Chloroflexi and Acidobacteria increased in the community coincided with increasing age of the dump, while the proportion of such phyla as Proteobacteria, Gemmatimonadetes and Bacteroides decreased. Also, with increasing age of the dump, the number of Archaea belonging to the phyla Crenarchaeota and Euryarchaeota decreases almost to zero. The decrease in Archaea abundance may be due to the replacement of their ecological niches (in particular, for the representatives of the phylum Crenarchaeota participating in nitrification processes) by bacteria in a more developed type of microbial community (Weidler, Gerbl and Stan-lotter, 2008).

Changes in the taxonomic composition of the prokaryotic community are associated with the transition from an unstable stage of development of an ecosystem characterized by the dominance of copiotrophic microorganisms (for example, bacteria from the genus Pseudomonas, bacteria from the family Enterobacteriaceae) to the climax type of a community with a predominance of Actinobacteria, the presence and high biodiversity of which indicate an effective process of transformation of soil organic matter (Goldfarb et al., 2011). In the 50-year-old dumps, the proportion of Streptomycetes and Nocardia increases; in particular, a reliable increase in the proportion in the community $(p<0.05)$ was found for families Micromonosporaceae, Nocardioidaceae, Microbacteriaceae, as well as bacteria of the family Gaiellaceae and order Solirubrobacterales typical in the soil of areas with a high value of the hydrothermal coefficient. The highest number of nucleotide sequences of the $16 \mathrm{~S}$ rRNA gene in the analyzed amplicone libraries was shown to belong to Proteobacteria from the Comammonadaceae family. All of them showed the greatest 
a

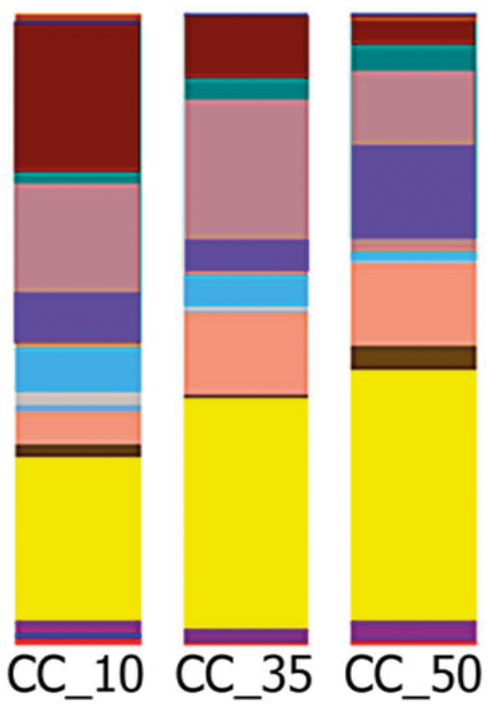

b

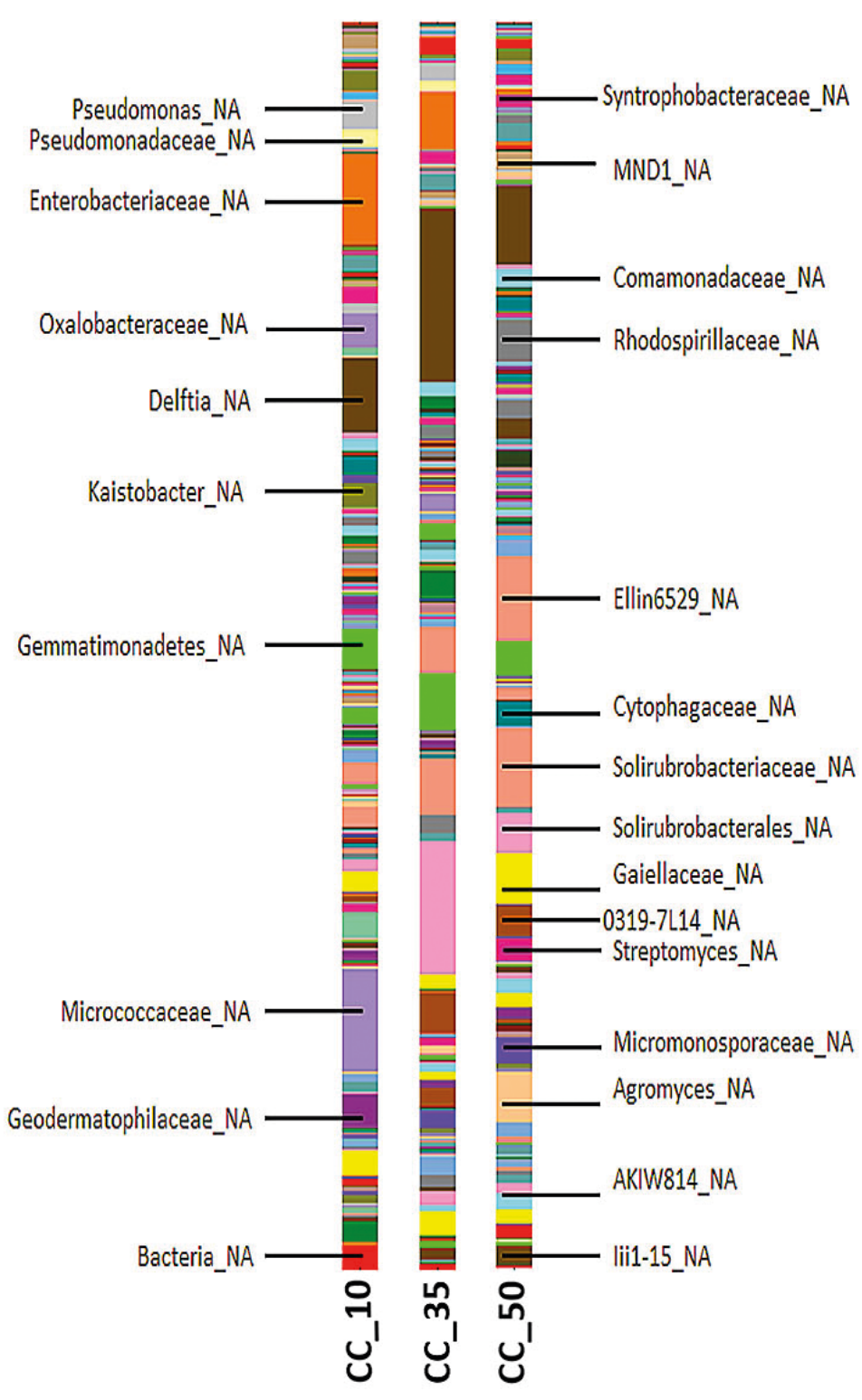

Fig. 1. Taxonomic structure of microbiomes inhabiting the embryozems formed on the overburden dumps of KMA at the phylum (a) and family/ genus (b) level.

similarity with the nucleotide sequences of the typical strain of Delftia tsuruhatensis. It is known that this microorganism is often associated with contaminated and technogenically disturbed soils, as well as with the microbial community of activated sludge (Hou et al., 2015). Possible participation of these bacteria in soil-forming processes was also confirmed by a peak-like change in their representation in the samples (Fig. 1b). For example, the number of these bacteria started to increase already in the 10-year-old dumps and reached a maximum in the 35-year-old dumps, after which it decreased.

It can be assumed that microbiological succession occurs even 35 years after the formation of the dump. This conclusion is confirmed by the analysis of the alpha and beta diversity of the studied microbiomes (Table 4 ).
Table 4. Indicators of alpha diversity of microbiomes inhabiting the embryozems formed on the overburden dumps of KMA. Data are presented as Mean \pm SE

\begin{tabular}{l|ccc}
\hline \multicolumn{1}{c|}{ Indices } & CC_10 & CC_35 & CC_50 \\
\hline Observed OTUs* & $373.3 \pm 139.0$ & $370.3 \pm 49.7$ & $466.3 \pm 9.6$ \\
PD_Faith** & $38.6 \pm 10.5$ & $35.6 \pm 3.9$ & $39.5 \pm 0.6$ \\
Shannon*** & $6.5 \pm 0.9$ & $6.6 \pm 0.6$ & $7.6 \pm 0.1$ \\
\hline
\end{tabular}

* Observed OTUs - total number of operational taxonomic units ** PD_Faith - an indicator of the phylogenetic diversity of Faith $\star * *$ Shannon - Shannon Index

Young (10-year-old and 35-year-old) dumps were characterized by similar parameters of alpha diversity (Table 4), indicating an unstable stage of ecosystem 


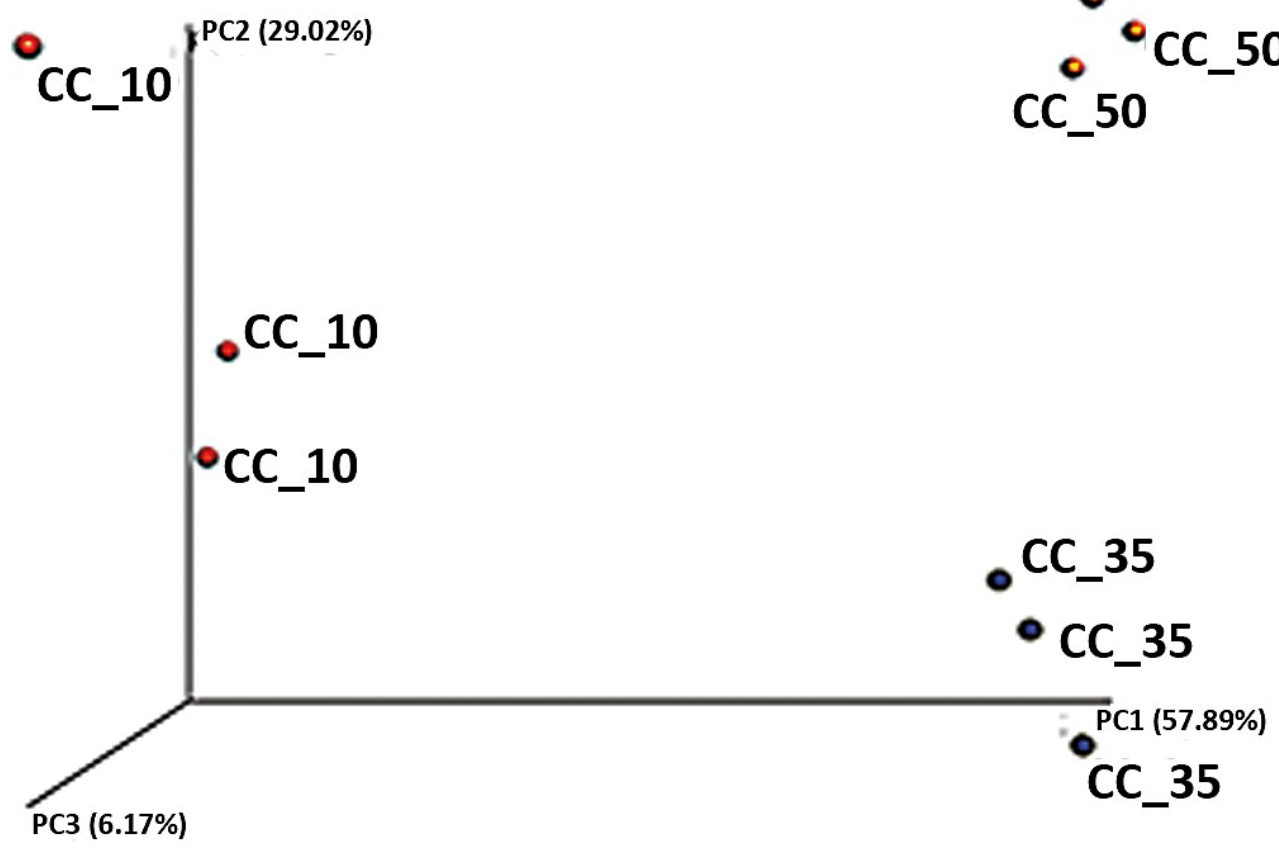

Fig. 2. PCoA-analysis of Weighted Unifrac distance matrix.

development. The number of species in the community, as well as the Shannon index, increased only in the 50-year-old dumps, which, according to these indirect indicators, can be characterized as the phase transitional to the termination (climax) stage of microbiological succession.

The multidimensional scaling of the distance matrix (Fig. 2) of the samples shows that the structure of microbiomes differed qualitatively and quantitatively in embryozems of different ages.

All the samples formed three separate clusters, according to the age of the dump. It is worth mention that the oldest samples (CC_50) formed the densest cluster, whereas the cluster of the youngest ones was more diffused. This can indirectly indicate more homogenous environment in 50-year old embryozems, which is important for microbiological colonization.

\section{Conclusions}

Based on the analysis of microbiological diversity, we evidenced that technogenic dumps formed by clay textured overburden rocks in the KMA region could be treated as a favorable niche for the development of microorganisms already at the earliest stages of soil formation. Even in 10 years embryonic soil microbial communities demonstrate a relatively high level of biological diversity. However, the increase in biodiversity indicators and the transition to a stable (climax) type of community were observed only 50 years after the formation of the dumps.
This is characterized by the replacement of copiotrophic forms of microorganisms by oligotrophic ones, among which the main role is played by various types of Actinobacteria.

\section{Acknowledgements}

The authors are grateful to A.Stefeev, Dr. S.-H. Sciences, Academician of the Academy of Natural Sciences, Professor FSBEI HPE FSBEI HPE Kursk State Agricultural Academy, for assistance in the selection of objects and the selection of samples for research.

\section{References}

Bradley, J.A., Singarayer, J.S., and Anesio, A. M. 2014. Microbial community dynamics in the forefield of glaciers. Proceedings of the Royal Society B: Biological Sciences 281(1795):20140882. https://doi.org/10.1098/ rspb.2014.0882

Brindukova, E. 2010. Patterns of accumulation of gross and mobile forms of heavy metals in chernozem of typical south-western forest-steppe. Author. Dis. Cand. Agricultural. Aciences. Kursk: KGSA. 19 p. (In Russian)

Caporaso, J.G., Kuczynski, J., Stombaugh, J., Bittinger, K., Bushman, F. D., Costello, E. K., Fierer, N., Peña, A. G., Goodrich, J. K., Gordon, J. I., Huttley, G. A., Kelley, S. T., Knights, D., Koenig, J. E., Ley, R. E., Lozupone, C. A., McDonald, D., Muegge, B. D., Pirrung, M., Reeder, J., Sevinsky, J. R., Turnbaugh, P.J., Walters, W. A., Widmann, J., Yatsunenko, T., Zaneveld, J., and Knight, R. 2010. QIIME allows analysis of high-throughput community sequencing data. Nature Methods 7(5):335-336. https://doi. org/10.1038/nmeth.f.303

Claassens, S., Rensburg, P.J.J.V.A. N., and Rensburg, L. V.A. N. 2006. Soil microbial community struc- 
ture of coal mine discard under rehabilitation. Water, Air, and Soil Pollution 174(1-4):355-366. https://doi. org/10.1007/s11270-006-9125-y

DeSantis, T.Z., Hugenholtz, P., Larsen, N., Rojas, M., Brodie, E. L., Keller, K., Huber, T., Dalevi, D., Hu, P., and Andersen, G. L. 2006. Greengenes, a chimera-checked 16S rRNA gene database and workbench compatible with ARB. Applied and Environmental Microbiology 72(7):50695072. https://doi.org/10.1128/AEM.03006-05

Dwivedi, V. and Soni, P. 2011. A review on the role of soil microbial biomass in eco-restoration of degraded ecosystem with special reference to mining areas. Journal of Applied and Natural Science 3(1):151-158. https://doi. org/10.31018/jans.v3i1.173

Dzionek, A., Wojcieszy, D., and Guzik, U. 2016. Natural carriers in bioremediation: A review. Electronic Journal of Biotechnology 23:28-36. https://doi.org/10.1016/j. ejbt.2016.07.003

Frouz, J. and Novakowa, A. 2005. Development of soil microbial properties in topsoil layer during spontaneous succession in heaps after brown coal mining in relation to humus microstructure development. Geoderma 129:5464. https://doi.org/10.1016/j.geoderma.2004.12.033

Gadd, G. M. 2019. Metals, minerals and microbes: geomicrobiology and bioremediation. Microbiology 156(3):609643. https://doi.org/10.1099/mic.0.037143-0

Goberna, M., Insam, H., Klammer, S., Pascual, J. A., and Sánchez, J. 2005. Microbial community structure at different depths in disturbed and undisturbed semiarid Mediterranean forest soils. Microbial Ecology 50(3):315-326. https://doi.org/10.1007/s00248-005-0177-0

Gomez-Alvarez, V., King, G. M., and Klaus, N. 2007. Comparative bacterial diversity in recent Hawaiian volcanic deposits of different ages. FEMS Microbiology Ecology 60(1):6073. https://doi.org/10.1111/j.1574-6941.2006.00253.x

Harantová, L., Frouz, J., Elhottová, D., and Baldrian, P. 2017. Development of microbial community during primary succession in areas degraded by mining activities. Land Degradation \& Development 28:2574-2584. https://doi. org/10.1002/ldr.2817

Hou, Q., Wang, C., Guo, H., Xia, Z., Ye, J., Liu, K., Yang, Y., Hou, X., Liu, H., Wang, J., Du, B., and Ding, Y. 2015. Draft genome sequence of Delftia tsuruhatensis MTQ3, a strain of plant growth-promoting rhizobacterium with antimicrobial activity. Genome Announcements 3(4):e00822-15. https://doi.org/10.1128/genomeA.00822-15

Kovda, V. 1965. Alkaline soda-saline soils. In Syrup. Sodic Soils. Budapest.

Nemergut, D. R., Anderson, S. P., Cleveland, C. C., Martin, A. P., Miller, A. E., Seimon, A., and Schmidt, S. K. 2007. Microbial community succession in an unvegetated, recently deglaciated soil. Microbial Ecology 53:110-122. https:// doi.org/10.1007/s00248-006-9144-7
Rana, S., Stahl, P. D., Ingram, L. J., and Wick, A. F. 2007. Soil microbial community composition in reclaimed soil under different vegetation in Wyoming minelands; pp.653661 in Thirty years of SMCRA and beyond: Proceedings of the $24^{\text {th }}$ National Meetings of the American Society of Mining and Reclamation, Gillette, WY. 2-7 June 2007. Curran Assoc., Red Hook, NY. https://doi.org/10.21000/ JASMR07010653

Schütz, K., Kandeler, E., Nagel, P., Scheu, S., and Ruess, L. 2010. Functional microbial community response to nutrient pulses by artificial groundwater recharge practice in surface soils and subsoils. FEMS Microbiology Ecology 72(3):445-455. https://doi.org/10.1111/j.15746941.2010.00855.x

Sprocati, A. R., Alisi, C., Tasso, F., Fiore, A., Marconi, P., Langella, F., Haferburg, G., Nicoara, A., Neagoe, A., and Kothe, E. 2014. Bioprospecting at former mining sites across Europe: microbial and functional diversity in soils. Environmental Science and Pollution Research 21(11):6824-6835. https://doi.org/10.1007/s11356-013-1907-3

Stifeev, A. and Golovastikova, A. 2015. Florogenesis of Callovian clay dumps of the Mikhailovsky career KMA; pp. 717-721 in Problems of waste, industrial and agricultural waste recycling. Krasnodar. (In Russian)

Stifeev, A., Golovastikova, E., and Bessonova, A. 2011. Changes in the composition and structure of a microbial community in the conditions of the technogenic landscape of the Mikhailovskyi ROP KMA. Vestnik Kurskoy Gosudarstvennoy Academii 4:40-41. (In Russian)

Sun, S., Li, S., Avera, B. N., Strahm, B. D., and Badgley, D. 2017. Soil bacterial and fungal communities show distinct recovery patterns during forest ecosystem restoration. Applied and Environmental Microbiology 83(14):e00966-17. https://doi.org/10.1128/AEM.00966-17

Thomas, T., Gilbert, J., and Meyer, F. 2012. Metagenomics - a guide from sampling to data analysis. Microbial Informatics and Experimentation 2(1):3. https://doi. org/10.1186/2042-5783-2-3

Weidler, G. W., Gerbl, F.W., and Stan-lotter, H. 2008. Crenarchaeota and their role in the nitrogen cycle in a subsurface radioactive thermal spring in the Austrian Central Alps. Applied and Environmental Microbiology 74(19):59345942. https://doi.org/10.1128/AEM.02602-07

Wolińska, A., Gałazka, A., Kuzniar, A., Goraj, W., Jastrzębska, Natalia, Grzadziel, J., and Stepniewska, Z. 2018. Catabolic fingerprinting and diversity of bacteria in Mollic Gleysol contaminated with petroleum substances. Applied Sciences 8:1-12. https://doi.org/10.3390/app8101970

Wolinska, A., Kuźniar, A., Szafranek-Nakonieczna, A., Jastrzębska, N., Roguska, E., and Stępniewska, Z. 2016. Biological activity of autochthonic bacterial community in oil-contaminated soil. Water, Air, and Soil Pollution 227(130):112. https://doi.org/10.1007/s11270-016-2825-z 